\title{
The Impact of Supplier Concentration on Credit Spreads in Corporate Bond Two Tier Market
}

\author{
Li Sun*, Tao Li \\ School of Economics and Management \\ Nanjing University of Science and Technology \\ Nanjing, China \\ 1102440342@qq.com
}

\begin{abstract}
The degree of supplier concentration has both benefit and risk effects. It is an important issue to discuss how to interpret the bond spreads of bonds in the two level market. In this paper, we use the study of corporate debt data in the two level market for 2009-2016 years in China. It is found that the degree of supplier concentration improves the bond credit margin, indicating that the overall degree of supplier concentration has a risk effect on the bond investors. For the first time, this paper explores the interpretation of the degree of supplier concentration by bond investors, which helps enrich the relevant literature in the field of suppliers and bonds.
\end{abstract}

Keywords-Supplier concentration; Company debt credit margin; Risk

\section{INTRODUCTION}

The asset price needs to make up for the possible default risk that the investor may bear. The price of this part is called the credit spreads, so the credit difference is an important issue of the two level market pricing of the corporate debt. The research shows that credit rating [1], information environment $(\mathrm{Yu}, 2005)$, internal factors of debt enterprises, and the economic environment (Longstaff and Schwartz, 1995), political risk [2] all affect the bond credit spreads. However, there is no literature to discuss the important Inter Organizational Relationship between suppliers -- the impact of suppliers on credit spreads

In the fierce competition of product market, supplier relationship has become the "magic weapon" for enterprises to gain market competitive advantage. First of all, supplier relationship helps enterprises to reduce transaction costs. Secondly, supplier relationship helps to ensure the quality of raw materials, thereby improving the efficiency and quality of product production, and enhancing the competitive advantage of the product market. Thirdly, when the relationship between enterprises and suppliers is close, the suppliers are willing to choose specific adjustments, including the flexible response to the unanticipated demand of the enterprises, so that the enterprises can react quickly to the market demand and then occupy the market. In the face of the positive impact of supplier relationship, enterprises have strong motivation to consolidate and strengthen their relationship with suppliers. In reality, supplier relationship is a double-edged sword, which will bring some negative effects while exerting positive influence. On the one hand, the loss of suppliers may lead to the stagnation of enterprise production when the proportion of the sales revenue of the supplier accounts for a larger proportion of the cost of the enterprise, that is, the higher the concentration of the supplier. Even if the buffer effect of inventory makes its short-term impact on the sales side of the enterprise limited, it may make the enterprise lose the opportunity to seize the market. On the other hand, if enterprises invest a lot of proprietary assets, the termination of the supplier relationship will lead to a large number of transfer costs, including the derogatory loss of the proprietary assets. In addition, due to the proprietary property of the proprietary assets, the liquidity is poor, it is difficult to bring the financing convenience through circulation or mortgage, which will further aggravate the financing constraints faced by the enterprises.

The bond investor is at a disadvantage in obtaining the internal information of the enterprise, so it may pay more attention to the public information such as the concentration of the supplier. Therefore, this paper mainly focuses on the role of the supplier concentration in the two level market company debt pricing. The literature focuses on supplier concentration, whether there is a large supplier, whether the supplier is a government background, and whether the supplier is stable or not, but because most enterprises do not disclose the detailed name of the supplier and only disclose the sales ratio, the supplier concentration is still the most important indicator of the supplier.

\section{LITERATURE REVIEW AND RESEARCH HYPOTHESIS}

\section{A. Research Literature on the Influence Factors of Bond Credit Spreads}

The study shows that macro factors such as risk-free interest rate and political uncertainty affect the credit spreads of bonds. Longstaff and Schwartz (1995) studies found that when the risk free interest rate is reduced, the value of the put option is reduced, the value of the bond is increased and the credit spread of the bond is reduced. The study of Duffee (1998) found that the price of redeemable bonds will rise and the credit spreads fall lower when the yield of the Treasury bonds rises. Other research [3] found that the greater the volatility of monetary policy, the greater the liquidity risk, the greater the credit spreads of bonds, the larger the scale of the credit, the better the product market environment, the investors will reduce the bond risk premium. 
However, few authors have discussed how suppliers affect the credit spreads of bonds. Many scholars believe that the basis of supply chain management is to understand supplier power and business strategy. Supplier management requires reducing the number of suppliers and avoiding redundancy in supplier relationship. The goal is to establish a long-term supplier relationship that can make the company profitable. The ultimate goal is to improve the quality and reduce the cost (Cox, 2015). The degree of supplier concentration refers to the proportion of an enterprise buying expenditure from one or several suppliers. The higher the supplier concentration is, the supplier is in a relatively strong position in the relationship with the enterprise.

\section{B. The Influence of Supplier Concentration on Credit Spreads of Corporate Bonds in the Two Tier Market}

The degree of supplier concentration may have an income effect, thereby reducing the credit spreads of bonds. Although not all relationships can bring the results of mutual benefit [4], good cooperative relations can reduce transaction costs, improve production efficiency, and bring good economic benefits to suppliers and suppliers (Kalwani and Narayandas, 1995). Suppliers are located upstream of the enterprise supply chain, and are important suppliers of raw materials needed by enterprises to produce products. For a long time, more and more enterprises have shifted from the traditional hostile relations with suppliers to looking for less and more stable suppliers, and establish long-term stability, mutual benefit and win-win cooperation with them. The relationship between suppliers and enterprises has also changed from the initial relationship through transaction to a "common governance" relationship .

The degree of supplier concentration may also have a risk effect, thereby increasing the credit spreads of bonds. Shepherd (2004) defines the market power of an enterprise itself, which is the ability of an enterprise to influence prices, contracts, assigning authority and others, and ultimately affecting profits. There are two forces in the market, one is the power of the buyer, the other is the power of the seller. Burgess (2006) defines buyer and seller power as buyer concentration, seller concentration, market share and seller's Association. The price of the transaction must be the result of the balance between the buyer's power and the seller's power. When the concentration of suppliers is raised, the seller is in a favorable position, the bargaining power of the seller is rising, and the price of the transaction is inclined to lower the transaction price, and the enterprise is at a disadvantage at this time. The reduction of the transaction price will directly affect the profit of the enterprise, which leads to the increase of business risk. The change in price and quality of suppliers may have an important impact on the production and operation of the enterprise, that is, the degree of dependence and the transfer cost of the enterprise to the supplier is higher [5]. It also indicates that, if the concentration of the suppliers is too high, the enterprise may depend on the supplier's supply very much because of the particularity of the raw material, and the supplier is in a strong position in the supply chain.

To sum up, the contrary hypothesis of this article is put forward.
Risk hypothesis H1, when other conditions remain unchanged, the higher the degree of supplier concentration, the greater the bond spreads.

Revenue hypothesis $\mathrm{H} 2$, when other conditions remain unchanged, the higher the degree of supplier concentration, the smaller the bond spreads.

\section{RESEARCH DESIGN}

\section{A. Model Design and Variable Definition}

In this paper, a model of [6] is used to build a model (1) to examine the relationship between supplier concentration and the credit spreads of corporate bonds in the two level market. The beta 1 is significantly greater than zero indicating that the supplier concentration has a risk effect, and vice versa is the return effect.

$$
\begin{aligned}
& \text { Spread }_{i, t}=\alpha+\beta_{1} \text { Supplier }_{i, t}+\beta_{2}{\text { BondContro } l_{i}+\beta_{3} \text { FirmContro }_{i, t}+\beta_{4} \text { Industry }}^{+\beta_{5} \text { Year }+\varepsilon_{i, t}}
\end{aligned}
$$

This paper uses bond yield at the end of the year to reduce the yield at the end of the year, and measure the bond spreads (Spread). Using [7], we use the Supplier Con (Supplier Con) to measure the supplier concentration (Supplier), and use the first largest supplier ratio (Supplier First) as the robustness test variable.

The control variables include the bond control variable (Bond Control) and the bond issuer (Firm Control).

1) Bond control variables include:

a)Bond size: X.Y.Wang (2015) found that the greater the volatility of monetary policy, the greater the liquidity risk, the greater the bond credit spread.

b)Bond term: R.Zhang(2010) show that the credit spreads of corporate bonds with short remaining maturities and high credit ratings are relatively low.

c)Bond rating: The credit rating can explain the bond credit spread, the higher the rating, the lower the credit spread [8].

d)Put: Duffee (1998) found that when the yield of government bonds rises, the price of bonds that can be sold back increases, and the credit spreads decrease.

2) Firm control includes: Due to the high cost of developing bond market terms and the low quality of accounting information, bond investors can only avoid risks by asking for higher financing costs. This paper selects the four financial indicators of the bond issuer as the representative of the accounting information, namely: the natural logarithm of the total assets (Size), the return on total assets (ROA), the growth rate of sales income (Growth), the debt ratio (Leverage ), SOE and Big4.

\section{B. Sample Selection and Data Sources}

This paper takes the annual data of the second-tier market corporate bonds of listed companies in Shanghai and Shenzhen as the initial sample, and makes the following 
screenings: (1) The floating interest rate bonds are eliminated because the credit spread cannot be calculated; (2) The redemption clause affects the credit Spreads but uncertain directions (Hsueh and Chandy, 1989), therefore eliminating redeemable bonds; (3) Excluding the annual data of bonds that did not disclose the total proportion of the top five suppliers; (4) Excluding samples with missing control variables. The final sample of 6,284 bonds of 783 companies, which accounted for the detailed proportion of the top five suppliers, was finally disclosed. The annual bond data and financial data are derived from CSMAR database. In order to avoid the extreme value impact, this paper has $1 \%$ up and down Winsorize processing for all variables.

\section{Descriptive Statistics}

Table I reports descriptive statistics for the main variables. The data shows: (1) The average credit spread of bonds is 2.293, the fluctuation range is from 0.292 to 6.139 , and the standard deviation is 1.294, which indicates that the distribution of bond credit spreads is basically reasonable. (2) The sales ratio of the top five suppliers accounted for $5.8 \%$, which indicates that the concentration of suppliers in China is not high; the average sales of the largest suppliers accounted for $14.9 \%$, indicating that suppliers have an important impact on enterprises. (3) The bond rating is about 5.753, indicating that the corporate bond has a higher credit rating; the SOE average is 0.624 , indicating that $62.4 \%$ of the samples are state-owned enterprises.

TABLE I. DESCRIPTIVE STATISTICS OF VARIABLES

\begin{tabular}{|l|l|l|l|l|l|l|}
\hline \multicolumn{2}{|c|}{ variables } & Mean & S.t & min & median & max \\
\hline Credit spread & Spread(\%) & 2.293 & 1.294 & 0.292 & 2.626 & 6.139 \\
\hline \multirow{4}{*}{$\begin{array}{l}\text { Supplier } \\
\text { concentration }\end{array}$} & Supplier Con & 0.058 & 0.122 & 0.000 & 0.014 & 2.108 \\
\cline { 2 - 7 } & Supplier First & 0.149 & 0.143 & 0.003 & 0.078 & 0.935 \\
\hline \multirow{5}{*}{ Bond Control } & Bond Size & 2.246 & 0.736 & 0.410 & 2.080 & 4.060 \\
\cline { 2 - 7 } & Bond Term & 1.328 & 0.846 & 0.000 & 1.390 & 2.200 \\
\cline { 2 - 7 } & Bond Rate & 5.753 & 0.846 & 4.000 & 5.000 & 7.000 \\
\cline { 2 - 7 } & Put & 0.683 & 0.466 & 0.000 & 1.000 & 1.000 \\
\hline \multirow{5}{*}{ Firm Control } & Size & 23.292 & 1.201 & 20.478 & 22.999 & 25.874 \\
\cline { 2 - 7 } & ROA & 0.024 & 0.047 & -0.448 & 0.022 & 0.151 \\
\cline { 2 - 7 } & Growth & 0.094 & 0.520 & -0.869 & 0.077 & 3.066 \\
\cline { 2 - 7 } & Leverage & 0.605 & 0.147 & 0.081 & 0.574 & 1.007 \\
\cline { 2 - 7 } & SOE & 0.624 & 0.484 & 0.000 & 0.000 & 1.000 \\
\cline { 2 - 7 } & Big4 & 0.102 & 0.302 & 0.000 & 0.000 & 1.000 \\
\hline
\end{tabular}

Table II reports the correlation coefficients of the main variables. The data shows that: (1) The relationship between supplier concentration and bond credit spread is significantly positive, which may indicate that bond investors in China's capital market interpret supplier concentration as a risk effect. However, the information connotation of the supplier concentration index is whether it is a risk effect or a revenue effect, and it cannot be determined for the time being. First of all, it is difficult to identify whether supplier concentration is risk or benefit without combining other characteristics of bonds and company characteristics. Secondly, the total manufacturing sample of this paper accounts for about $62 \%$, while the concentration of suppliers in the manufacturing sample is The correlation coefficient of bond credit spreads is positive but not significant. Finally, bond issuance is mainly concentrated in 2013-2016.

TABLE II. CORRELATION COEFFICIENT OF MAIN VARIABLES

\begin{tabular}{|l|l|l|l|l|l|l|l|}
\hline variables & Spread & $\begin{array}{c}\text { Supplier } \\
\text { Con }\end{array}$ & $\begin{array}{c}\text { Bond } \\
\text { Size }\end{array}$ & Size & ROA & $\begin{array}{c}\text { Growt } \\
\mathbf{h}\end{array}$ & Leverage \\
\hline $\begin{array}{l}\text { Supplier } \\
\text { Con }\end{array}$ & $0.1556^{*}$ & 1.000 & & & & & \\
\hline $\begin{array}{l}\text { Bond } \\
\text { Size }\end{array}$ & $-0.2825^{*}$ & -0.007 & 1.000 & & & & \\
\hline Size & $-0.4881^{*}$ & 0.0099 & $0.5660^{*}$ & 1.000 & & & \\
\hline ROA & $0.1703^{*}$ & 0.0112 & $-0.2785^{*}$ & $-0.4120 *$ & 1.000 & & \\
\hline Growth & $-0.3539^{*}$ & -0.0736 & $0.7207 *$ & $0.6151 *$ & $-0.3834 *$ & 1.000 & \\
\hline Leverage & $-0.3467^{*}$ & $-0.1443 *$ & $-0.0970 *$ & 0.0012 & 0.0317 & -0.088 & 1.000 \\
\hline
\end{tabular}

\section{EMPIRICAL RESULT AND ANALYSIS}

Table III (1) data shows: the regression coefficient of the top five suppliers' sales ratio (Supplier Con) to the company's credit spread (Spread) It is 0.843 and is significant at the $1 \%$ level, indicating that the higher the concentration of suppliers, the greater the bond credit spread, the concentration of suppliers leads to higher risk premiums for bond investors. In order to ensure the stability of the results, column (2) of Table III made an industry annual median adjustment to the supplier concentration index to avoid the impact of annual differences in the industry. Table III (3) uses bonds and annual twodimensional clustering to be robust. In terms of bond characteristics, the bond rate (Board Rate) is significantly negatively correlated with the bond credit spread, indicating that the higher the rating, the smaller the bond credit spread, which is consistent with the study by Ziebart and

Reiter(1992).

In terms of company characteristics, the regression coefficients of Size and ROA are significantly negative, indicating that the larger the company size, the higher the return on assets, the smaller the bond credit spread; the positive coefficient of Growth and Leverage indicates that the company's growth is higher, the debt ratio The higher the bond credit spread is, the higher. The regression coefficient of SOE is significantly negative at the $1 \%$ level, indicating that the credit spread of state-owned bonds is lower.

\section{RoBUstness Test}

This paper makes the following robustness processing:Change supplier concentration and credit spread measurement, measure supplier concentration with the first largest supplier ratio, and use the bond maturity rate minus the one-year bank time deposit rate or bond maturity The rate 
minus the People' s Bank of China announced the five-year fixed deposit rate to measure the credit spread.

TABLE III. IMPACT OF SUPPLIER CONCENTRATION ON BOND CREDIT SPREADS

\begin{tabular}{|c|c|c|c|}
\hline variables & Basic OLS & $\begin{array}{c}\text { Industry } \\
\text { annual } \\
\text { median } \\
\text { adjusted OLS }\end{array}$ & $\begin{array}{c}\text { Industry annual } \\
\text { median } \\
\text { adjustment } \\
\text { And do the } \\
\text { Cluster } \\
\text { processing } \\
\end{array}$ \\
\hline & (1) & (2) & (3) \\
\hline Supplier Con & $\begin{array}{l}0.843 * * * \\
(2.85) \\
\end{array}$ & $\begin{array}{l}0.926^{* * *} \\
(3.11)\end{array}$ & $\begin{array}{l}0.926^{* * *} \\
(3.03)\end{array}$ \\
\hline Bond Size & $\begin{array}{l}-0.103 \\
(-1.43) \\
\end{array}$ & $\begin{array}{l}-0.098 \\
(-1.35) \\
\end{array}$ & $\begin{array}{l}-0.098 \\
(-1.22) \\
\end{array}$ \\
\hline Bond Term & $\begin{array}{l}-0.01 \\
(-0.47)\end{array}$ & $\begin{array}{l}-0.02 \\
(-0.92)\end{array}$ & $\begin{array}{l}-0.02 \\
(-0.45)\end{array}$ \\
\hline Bond Rate & $\begin{array}{l}-0.558 * * * \\
(-9.38)\end{array}$ & $\begin{array}{l}-0.490 * * * \\
(-8.64)\end{array}$ & $\begin{array}{l}-0.490 * * * \\
(-6.37)\end{array}$ \\
\hline Put & $\begin{array}{l}-0.101 \\
(-1.19)\end{array}$ & $\begin{array}{l}-0.065 \\
(-0.78)\end{array}$ & $\begin{array}{l}-0.065 \\
(-0.64)\end{array}$ \\
\hline Size & $\begin{array}{l}-0.164 * * * \\
(-3.00)\end{array}$ & $\begin{array}{l}-0.188 * * * \\
(-3.53)\end{array}$ & $\begin{array}{l}-0.188^{* * *} \\
(-3.00)\end{array}$ \\
\hline ROA & $\begin{array}{l}-8.402 * * * \\
(-9.50)\end{array}$ & $\begin{array}{l}-8.149 * * * \\
(-9.14)\end{array}$ & $\begin{array}{l}-8.149 * * * \\
(-5.20)\end{array}$ \\
\hline Growth & $\begin{array}{l}0.018 \\
(0.26)\end{array}$ & $\begin{array}{l}0.025 \\
(0.36)\end{array}$ & $\begin{array}{l}0.025 \\
(0.35)\end{array}$ \\
\hline Leverage & $\begin{array}{l}0.924 * * * \\
(2.74)\end{array}$ & $\begin{array}{l}1.026^{* * * *} \\
(3.07)\end{array}$ & $\begin{array}{l}1.026^{* * *} \\
(2.96)\end{array}$ \\
\hline SOE & $\begin{array}{l}-0.469 * * * \\
(-5.93)\end{array}$ & $\begin{array}{l}-0.414 * * * \\
(-5.52)\end{array}$ & $\begin{array}{l}-0.414 * * * \\
(-6.42)\end{array}$ \\
\hline Big4 & $\begin{array}{l}0.103 \\
(0.77) \\
\end{array}$ & $\begin{array}{l}0.114 \\
(0.85) \\
\end{array}$ & $\begin{array}{l}0.113 \\
(1.06) \\
\end{array}$ \\
\hline $\begin{array}{ll}\text { Year } & \& \\
\text { Industry } & \\
\text { Fixed } & \end{array}$ & YES & YES & YES \\
\hline Observations & 6284 & 6284 & 6284 \\
\hline $\begin{array}{l}\text { Adjusted - } \\
\mathrm{R}^{2}\end{array}$ & 0.487 & 0.487 & 0.486 \\
\hline $\mathrm{F}$ 值 & 25.77 & 25.75 & 25.76 \\
\hline
\end{tabular}

TABLE IV. ROBUSTNESS TEST

\begin{tabular}{|l|l|l|}
\hline \multicolumn{1}{|c|}{ variables } & \multicolumn{1}{c|}{$\begin{array}{c}\text { Regression } \\
\text { coefficients }\end{array}$} & T-value \\
\hline Supplier First & $0.709^{* * *}$ & 2.73 \\
\hline Bond Size & -0.105 & -1.44 \\
\hline Bond Term & -0.059 & -0.28 \\
\hline Bond Rate & $-0.558^{* * *}$ & -9.43 \\
\hline Put & -0.109 & -1.31 \\
\hline Size & $-0.171^{* * *}$ & -3.12 \\
\hline ROA & $-8.421^{* * *}$ & -9.35 \\
\hline Growth & 0.011 & 0.17 \\
\hline Leverage & $0.989^{* * *}$ & 2.95 \\
\hline
\end{tabular}

\begin{tabular}{|l|l|l|}
\hline \multicolumn{1}{|c|}{ variables } & \multicolumn{1}{|c|}{$\begin{array}{c}\text { Regression } \\
\text { coefficients }\end{array}$} & \multicolumn{1}{c|}{ T-value } \\
\hline SOE & $-0.472^{* * *}$ & -5.97 \\
\hline Big4 & 0.109 & 0.82 \\
\hline $\begin{array}{l}\text { Year \& Industry } \\
\text { Fixed }\end{array}$ & YES \\
\hline Observations & 6284 \\
\hline Adjusted $-\mathrm{R}^{2}$ & 0.483 \\
\hline F 值 & 25.71 \\
\hline
\end{tabular}

We found in Table IV that the regression results remained unchanged. Supplier First had a regression coefficient of 0.709 for the company's credit spread, and was significant at the $1 \%$ level, indicating that the higher the degree of supplier concentration, the greater the bond spreads.This paper illustrates the robustness of $\mathrm{H} 1$ assume in this paper.

\section{CONCLUSION}

This paper examines the impact of supplier concentration on bond credit spreads. The conclusions show that bond investors are more inclined to interpret supplier concentration as risk and then higher risk premium, and supplier concentration is indeed a risk. This paper first discusses the interpretation of supplier information by bond investors, and helps to understand the formation mechanism of bond credit spreads from the perspective of suppliers.

\section{REFERENCES}

[1] X.Y. Wang and C.Q. Zhang, "Reputation Mechanism, Credit Rating and Medium-Term Bill Financing Cost," Financial Research, vol. ED-8, pp. 150-164, 2013.

[2] D.L. Luo and G.M. She, "Changes in local officials and local debt issuance," Economic research, vol. ED-6, pp. 131-146, 2015.

[3] X.Y. Wang, C.Q. Zhang and J. He, "Macroeconomic volatility and short-term securities risk premium," Financial Research, vol. ED-1, pp. 68-83, 2015.

[4] D. Narayandas and V.K. Rangan, "Building and Sustaining Buyer-seller Relationships in Mature Industrial Markets," Journal of Marketing, vol. ED-3, pp. 63-77, 2004.

[5] Y.J. Tang, "Bargaining Ability of Suppliers and Distributors and Corporate Performance:Empirical Evidence from Chinese Manufacturing Listed Companies in 2005-2007," China Industrial Economy, vol. ED-10, pp. 67-76,2009.

[6] J. Jiang, "Beating Earnings Benchmarks and the Cost of Debt," The Accounting Review, vol. ED-2, pp. 377-416, 2008.

[7] D.Dhaliwal, J.S.Judd, M.Serfling and S. Shaikh, "Customer Concentration Risk and the Cost of Equity Capital," Journal of Accounting and Economics, vol. ED-1, pp. 23 -48, 2016.

[8] D.A. Ziebart and S.A. Reiter, "Bond Ratings,Bond Yields and Financial Information," Contemporary Accounting Research, vol. ED-1, pp. 252282, 1992. 